$\begin{array}{lll}\text { Journal of } & \text { Vol 1 (1): Pages 16-19 (2020) } \\ \text { SUSTAINABLE } & \text { DOI 10.37357/1068/iser.1.1.03 } \\ \text { ENERGY } & \text { ISSN 2435-7251 } \\ \text { REVOLUTION } & \text { A) check for updates }\end{array}$

\title{
Energy related implications for clean, livable, and smart Kabul: A policy recommendation for the energy sector and urban sector of Afghanistan
}

\author{
Najib Rahman Sabory ${ }^{1}$, Mir Sayed Shah Danis ${ }^{1,2}$ and Tomobobu Senjyu \\ ${ }^{1}$ Department of Energy Engineering, Faculty of Engineering, Kabul University, Kabul, Afghanistan \\ ${ }^{2}$ Strategric Reserch Profects Center, University of the Ryukyus, Okianwa, Japan \\ ${ }^{3}$ Department of Electrical and Electronics Engineering, Faculty of Engineering, University of the Ryukyus, Okinawa, Japan
}

\section{Special Issue Article Open Access Published}

Keywords

- Sustainable energy

- Plicy instrument

- Renewable energy

- Smart city

- Urban planning

- Urban design

- Master plan

- Urban design framework

- Kabul city sustainable development

\section{ABSTRACT}

Cities are predicted to host $80 \%$ of the populations by 2050 consiering the current urbanization rate. It is inevitable. No choice is left to us but to keep our cities clean and livable. Efficient use of energy is tightly linked with the smart cities. Looking at the technology development trends and the extensive need for efficient use of energy, cities must be transforming to smart ones in order to keep them clean and livable for this and generations to come. Kabul city population has been growing so rapidly and also expanding widely to its outskirts in the last two decades. Environmental footprints has been so significant and diverse. One of the critical issue with Kabul city has been the access to clean and abundant sources of Energy. At the same time, lack of a master plan for its future has made this city in the danger of become empty from the habitants in few decades. This is very important to draw future now. Develop a new vision for our cities that is meeting the requirements of future. Kabul city needs one badly. One important area of a city to be discussed is its energy demand, supply and consumption. In this research, energy demand, sustainable sources of energy supply and consumption is thoroughly discussed. Based on our key assumption, livable and clean Kabul, all the other parameters are analyzed and suggested. In specific, we have discussed the energy demand for electricity, heating and cooling of buildings, transportation and industry. It is also assumed that Kabul will be modern and smart city with state of the art technology available all around it. Key data and references for this research are; 1 . Sasaki Urban Design Framework for Kabul city, 2. Previous master plans of Kabul city, 3. Energy strategies and outlooks for Afghanistan, 4. Sustainable Development Goals (SDGs) and many other guidelines internationally used for urban planning and design. This research will help policy makers, urban planners and designers, municipality authorities, other urban issues related sectors to work jointly and make smart and rational decisions for the capital of Afghanistan and save it from going abandoned.

Received: January 17, 2020; Revised: March 16, 2020; Accepted: March 20, 2020; Published: June 05, 2020

\section{Introduction}

Why smart and sustainable? Around $75 \%$ of the all-natural resources are consumed by cities including $60-80 \%$ of greenhouse emission, while takes up only a small portion of the land on the earth [1]. Future smart cities will rely on reliable, efficient and low carbon energy supply [2]. World agreed on 17 goals to achieve by 2030 that is impossible to achieve by the innovations and serious and ambitous planning by cities [3]. Goal 7 the provision of affordable and clean energy, goal 8 decent work and economic growth, goal 9 the industry, innovation and infrastructure, and goal 11 sustainable cities communities, are directly and closely related to sustainable and smart cities. Action fields of smart cities are focusing on these 6 areas : 1.Smart Governance, 2. Smart Economy, 3. Smart Mobility, 4. Smart Environment, 5. Smart People, and 6. Smart Living. All these action fields somehow related to energy and ICT. For example, According to IEA analysis presented in the Energy Technology Perspectives 2016 [4], the gradual evolution of urban transport systems to encourage walking, cycling and public transit could save $\$ 21$ trillion by 2050, while at the same time making a significant dent in greenhouse gas emissions. As mentioned, cities are predicted to host $80 \%$ of the populations by 2050 condiering the current urbanization rate [5]. These global changes in cities will affect urban planning [6]. Sometime the green city is interchangabelly used with smart and sustainable cities."The Green City Index was originally subdivided into eight categories: CO2 emissions, energy, buildings, transport, water, waste and land use, air quality and environmental governance" [7].

Kabul, the capital of Afghanistan has been growing very fast since 2001. Its population dramatically increased from nearly $01 \mathrm{M}$ to $4.5 \mathrm{M}$ [8]. A city that was built for $1 \mathrm{M}$ has to contain this new population. It has put politicians and Kabul city authorities in a tough position on how to provide all the means of a quality living to its citizens. Although it is not a fully resolved equation for high class and developed cities around the globe, but the concern of accommodating and providing living facilities for its citizen according to SDGs provisions, is very critical and hard to tackle in an under-developed capital, Kabul. There are number of organizations active around the globe for identifying targets and indicators for smart and sustainable 
cities. ITU, United Nations, ISO and some others are among them to name [9]. However, to adapt in the first step and then managing the implementation of these targets and approaching to their identified goals has put a high burden on city leaders.

This research will help policy makers, urban planners and designers, municipality authorities, other urban issues related sectors to work jointly and make smart and rational decisions for the capital of Afghanistan and save it from going abandoned.

\section{Problem statement}

There are both global level and local level problems associated with cities. Climate change conerns due to fossil fuel consumption is a global concern. There are targets set by UN Framework Convention on Climate Change (UNFCCC) to reduce greenhouse gas emission [10]. On the other hand, local concerns associated with energy consumption has been equally important issue. Government of Afghanistan has set an ambitious target to generate $95 \%$ of its energy from renwable energy resources by 2032 [11]. However no framework and strategy has yet been developed to take them to this target. Government of the Islamic Republic of Afghanstan in related to the SDGs, has set a target to increase access to affordable, reliable and modern electricity from $30 \%$ in 2016 to $80 \%$ (no target set for the expansion of renewable energy, energy efficiency and improvement) by 2020 [12].
Again, no clear roadmap and frameworks for these visions exist. Recently, a design framework for Kabul city (KUDF) is developed pointing to the sustainable energy provisions for Kabul city. But, it only discusses this topic in the city level, talking about substations expansion, renewable energy projects, energy efficiency improvement, rooftop solar hot water, waste to energy and a number of policy recommendations for the lower level [13]. However, they have not pointed out to any national or citylevel targets for $\mathrm{CO} 2$ emissions reduction and energy targets. ICT and IoT which is one of the pre-requisites of the smart city is not considered at all in KUDF. Most of the industrial parks are still running of diesel generator that costs around 60 cents per Kwh while the price of the grid electricity is 10 cents for industrial users [14]. Considering all the above issues, it can be said that there is no policy or plan existing that draw a smart and sustainable future for Kabul city, which is one of the global as well as local requirements for modern and new generation of cities.

\section{Solution mechanism}

A sustainable solution for these problems is the existence of a framework, where all the stakeholders are able to come togather, and identify and set national targets for takcing these problem. A preliminary and high level framework is proposed in Figure 1.

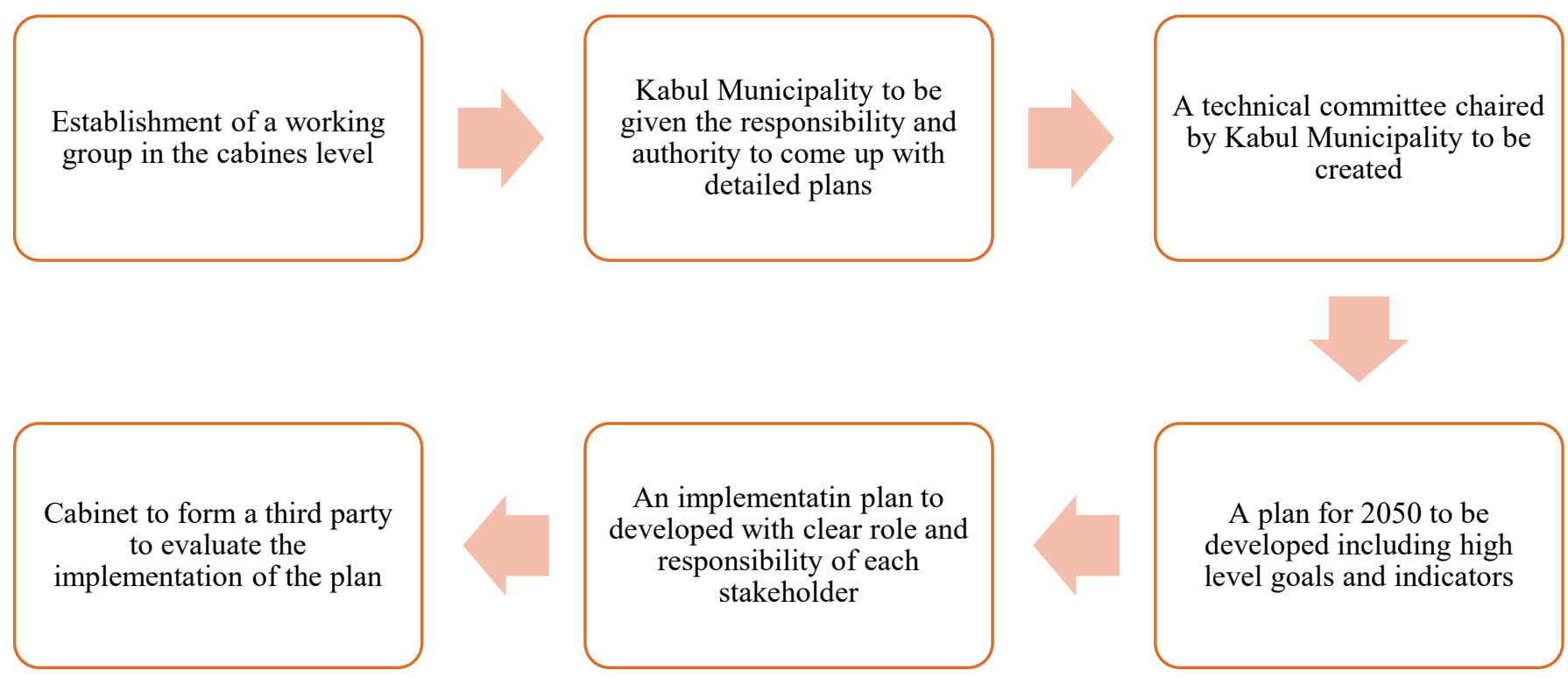

Figure 1. Proposed framework for a smart and sustainable Kabul

According to this framework, the government, in the cabinet level is suggested to set some national targets for big cities of Afghanistan, specifically for the capital, Kabul city. In the next level, relevant ministries and entities are supposed to prepare there plans and goals based on this national targets.
An evaluation and measurement mechanism is also proposed to be developed in order to track the progress, identify chockpoints and bottlenecks, and prepare regular reporting of each entity. 


\section{Methodology}

In this research, a number of reports, papers, urban plans related to energy integration in the urban planning processes has been reviewed. Based on the findings and suggestions of these literature and practices, a high level framework is prepared as shown in Figure 1.

\section{Result and discussion}

The main findings of this research is focusing on lack of a framework for considering integrating of energy, sustainability and smart cities indicators for Kabul city urban development and design framework. It shows that there is issues in the policy and political level that has left out this important topic in the urban development equation. Therefore, some policy recommendations are proposed for the policy makers to enable them start discourse in the urban development context.

Kabul municipality need to empower its policy and planning team by adding another department to deal with the ICT and IoT matter which is key for designing a smart and sustainable city. In addtion to this team, a strong planning team need to be in place in order to transition Kabul to a smart and sustainable city.

\section{Findings}

From this research, it is revealed that there are some efforts and debates that is discussing this important issue in different levels of the government and Kabul city, but there is no national consensus on how the problems of Kabul city and other major cities such as Herat, Kandahar, Jalalabad and Mazar e Sharif could be solved. The leading body to consider energy integration in urban planning processes, is missing. There are different sources of complexity in including energy issues in urban planning as detailed by Rittel and Webber [15]. Some are listed below that is true in the context of Kabul city:

1- Lack of a single problem statement

2- Conflicting values

3- Conflicting objectives

4- Multiple tactics to address the problems

5- Multiple actors with the power to assert their values

6- Scientific complexity and uncertainty

7- Political complexity and uncertainty

8- Administrative complexity and uncertainty

9- Dynamic context

\section{Conclusion and recommendations}

To make Kabul a livable, smart and sustainable, government need to take immediate and strong steps. Kabul, the most polluted city in Afghanistan, will not be anymore a good place unless sustainability for this city is included in the national security agenda. Kabul municipality as the leading entity should step in and propose specific targets and goals for the short, medium and long term of this city. Below are specific recommendation to save Kabul and make it a city where the modern world expects:

10-Prepare a strategic plan where sustainability and smartness is the main agenda

11-Raising awareness about SDGs and climate change plans for municipalities and city residents.

12- Develop an integrated city plan where SDGs and smart -sustainable city indicators require

13- Limit the role of state power utility (DABS) and MEW and give more role and responsibility to Kabul municipality.

14- Develop and enforce energy code for buildings to ensure better performance, especially in commercial and administrative buildings.

15- Developing a comprehensive and efficient transportation network advocating fast transit systems to decrease energy consumption and congestion.

16-Encouraging the use of solar energy in many applications (such as Solar Rooftop and water heaters and street lighting)

17- Establishing a strong and independent Energy regulatory body for Kabul city

18-Increase private sector engagement

19- Promoting planting designated green areas but using ecological landscapes and choosing suitable plants that are responsive to the Kabul climate and that require less maintenance.

\section{References}

[1] Dodman D, Diep L, Colenbrander S (2017) "Resilience and resource fffciency in cities" Nairobi, Kenya, United Nations Environment Programme (UNEP). (https://wedocs.unep. org/bitstream/handle/20.500.11822/20629/Resilience_resource_efficiency_cities.pdf?sequence=1\&amp\%3BisAllowed=) Accessed: 1 November 2019

[2] Batty M, Axhausen KW, Giannotti F, Pozdnoukhov A, Bazzani A, et al. (2012) "Smart cities of the future" The European Physical Journal Special Topics (vol. 214, no. 1, pp. 481-518) https://doi.org/10.1140/epjst/e2012-01703-3

[3] United Nations (UN) (2020) "Sustainable Development Goals (SDGs)" (https://sustainabledevelopment.un.org/ sdgs) Accessed: 1 November 2019

[4] Energy technology perspectives 2016: Towards sustainable urban energy systems (2016) Executive summary Paris, France, International Energy Agency (IEA). (https://webstore.iea.org/download/summary/1057) Accessed: $1 \mathrm{No}$ vember 2019

[5] World urbanization prospects (2019) The 2018 revision New York, USA, United Nations (UN). (https://population.un.org/wup/Publications/Files/WUP2018-Report.pdf) Accessed: 1 November 2019 
[6] Cajot S, Peter M, Bahu J-M, Koch A, Maréchal F (2015) "Energy Planning in the Urban Context: Challenges and Perspectives" Energy Procedia (vol. 78, pp. 3366-3371) https://doi.org/10.1016/j.egypro.2015.11.752

[7] Essam E. Khalil HA, Khalil EE (2019) "Energy efficiency in the urban environment," 1st ed. Florida, USA, CRC Press. 304 p. ISBN: 978-0-367-37781-6

[8] Central Statistics Organization (CSO) (2019) "Afghanistan statistics" (http://cso.gov.af/fa) Accessed: 1 November 2019

[9] Huovila A, Bosch P, Airaksinen M (2019) "Comparative analysis of standardized indicators for Smart sustainable cities: What indicators and standards to use and when?" Cities (vol. 89, pp. 141-153) https://doi.org/10.1016/j.cities.2019.01.029

[10] United Nations Environment Programme (UNEP) (2011) "Seventeenth session of the Conference of the Parties (COP 17)" Seventeenth session of the Conference of the Parties (COP 17) (https://unfccc.int/process-and-meetings/conferences/past-conferences/durban-climate-change-conference-november-2011/cop-17) Accessed: 1 November 2019
[11] Ministry of Energy and Water (MEW) - Afghanistan (2017) "Afghanistan Renewable Energy Policy" (Afghanistan Renewable Energy Policy) Accessed: 16 November 2019

[12] Voluntary national review at the high level political forum SDGs' - Afghanistan (2017) Progress report Kabul, Afghanistan, General Directorate of Policy \& RBM, Ministry of Economy. (https://sustainabledevelopment.un.org/content/documents/16277Afghanistan.pdf) Accessed: 4 July 2020

[13] Sasaki (2017) "Kabul urban design framework," 1st ed. Kabul, Afghanistan, Ministry of Urban Development and Housing. (https://www.sasaki.com/projects/kabul-urban-design-framework/) Accessed: 1 November 2019

[14] Institutional Development for Energy in Afghanistan (IDEA) Programme - GIZ (2017) "Enabling PV Afghanistan" Berlin, Germany, Institutional Development for Energy in Afghanistan (IDEA) Programme - GIZ. (https://www.solarwirtschaft.de/fileadmin/user_upload/report_enabling_pv_afg.pdf) Accessed: 1 November 2019

[15] Rittel HWJ, Webber MM (1973) "Dilemmas in a general theory of planning” Policy Sci (vol. 4, no. 2, pp. 155-169) https://doi.org/10.1007/BF01405730 